\title{
Devil is in the detail: behaviorally explicit habitat selection by the Critically Endangered great Indian bustard
}

\author{
Sutirtha Dutta*, Yadvendradev Jhala \\ Department of Animal Ecology Conservation Biology, Wildlife Institute of India, Chandrabani PO Box 18, \\ Dehradun 248001, India
}

\begin{abstract}
Habitat management to accommodate ecological needs of threatened species can help abate biodiversity decline. Some species require contrasting microhabitats for different functions, and may prefer patches with ample, diverse microhabitats. We examined this problem for the Critically Endangered great Indian bustard Ardeotis nigriceps in $175 \mathrm{~km}^{2}$ breeding habitat in Kachchh, India. We developed behaviorally explicit resource selection functions (RSFs) by comparing used vs. available microhabitats using binomial generalized linear models that tested hypothesized habitat responses in an information theoretic framework. We identified suitable resource units based on fitted RSF values. We examined if availability of complementary resource units influenced density/usage at the patch level, using line transect distance sampling. Birds preferred agro-vegetation mixture, grassland, high fruit abundance and intermediate grazing density, and they avoided Prosopis thickets for foraging. They preferred moderately tall sward for day resting but shorter sward and less Prosopis for roosting. Nesting females preferred grasslands with relatively tall sward and abundant insects, while displaying males preferred grasslands with shorter sward, far from settlements. Thus, microhabitat selection differed between behaviors and differed from habitat availability. The RSF without behavioral segregation failed to capture these nuances and was non-informative for habitat management. Density/usage at the patch level was correlated with the availability of complementary microhabitats. Thus, protected area management to accommodate diverse life-history requirements may reduce species' movements over large hostile landscapes and associated mortality. Overall, species requiring complementary microhabitats will benefit from management that promotes habitat heterogeneity. However, habitat use analysis based on behaviorally inexplicit occurrence cannot capture the habitat quality of such species.
\end{abstract}

KEY WORDS: Ardeotis nigriceps - Conservation - Grasslands - Habitat restoration - Behavior · Foraging $\cdot$ Resource selection function $\cdot$ Distance sampling

\section{INTRODUCTION}

Fourteen percent of the world's birds are threatened (IUCN 2018), with particularly steep declines among Indo-Malayan species (Butchart et al. 2004). Reduced fitness in altered habitats has caused much of these declines (Tilman et al. 1994), but corrective habitat

\footnotetext{
${ }^{*}$ Corresponding author: sutirthadutta@gmail.com
}

manipulation can abate these trends. Hence, understanding resource selection and supplementing preferred resources in breeding areas have benefited many birds. For instance, a study highlighting the importance of tall marsh vegetation and late mowing for corncrake Crex crex (Green 1996) recommended actions such as delayed mowing that facilitated the re-

() The authors 2021. Open Access under Creative Commons by Attribution Licence. Use, distribution and reproduction are unrestricted. Authors and original publication must be credited. 
covery of this species (O'Brien et al. 2006). However, information on habitat use is lacking for many threatened species. This is particularly concerning for grasslands that are rapidly changing and require urgent conservation interventions (White et al. 2000). Bird populations are declining faster in grasslands than other biomes of many regions owing to habitat loss, afforestation, mismanagement, land-use intensification and fragmentation (Hovick et al. 2014, SoIB 2020).

Grassland birds may select complementary habitats to meet their diverse ecological needs (Law \& Dickman 1998). Habitat selection differs between nesting and feeding usage for short-toed larks Calandrella brachydactyla (Serrano \& Astrain 2005) and black kites Milvus migrans (Sergio et al. 2003). Hence, habitat choice should be assessed across multiple behaviors and scales for comprehensive understanding and holistic management. Species depend on landscape complementation when their abundance at larger scales is constrained by the availability of complementary resources at smaller scales (Dunning et al. 1992). For these species, availability of complementary resources can enable higher usage of an area, by reducing energetic costs of movements, diminishing predation risk and attracting birds (Choquenot \& Ruscoe 2003). Alternatively, usage by birds may be concentrated if complementary resources are available in proximity, but diffused over a larger area if complementary resources are spatially disjoint. Bustards (family Otididae), a group of globally threatened grassland birds, offer an ideal system to test this postulate because of their requirement for heterogeneous habitats and growing dependence on conservation efforts (Collar et al. 2017).

The great Indian bustard Ardeotis nigriceps is Critically Endangered with around 100-150 birds left in India and Pakistan (Dutta et al. 2011, BirdLife International 2018). Its habitats, mainly arid-semiarid grasslands, are marginalized as 'unproductive wastelands' and are experiencing infrastructural development and intensive land uses (Dutta 2018). The Indian government is implementing recovery actions for this species that include restoration of breeding habitats (Dutta et al. 2013). Enclosures are being established in Thar (Rajasthan), Kachchh (Gujarat) and other range areas, to reduce anthropogenic disturbances, increase herbaceous cover and improve breeding success. Since the species faces high mortality risk due to power-line collisions, habitat management to increase bird density/usage in infrastructure-free protected enclosures can aid in the recovery of this species.

Inferences on habitat suitability by comparing used vs. available locations have a long history in conser- vation applications (Boyce \& McDonald 1999). These statistical models can explain species-habitat relationships and predict where species are distributed, and they are frequently applied to manage habitats of endangered species (Rushton et al. 2004). Despite the growth of resource selection analysis, even involving machine learning approaches (Shoemaker et al. 2018), their application is not behaviorally explicit. Their inferences can be biased towards more detectable behaviors, ignore resource requirements for elusive behaviors and run the risk of recommending measures that do not encompass the diversity of ecological needs of a species. Rahmani (1989) qualitatively described different microhabitats used by great Indian bustards. However, a comprehensive assessment of the species' resource selection across behaviors, and the interplay of space-use decisions across scales, is lacking. These insights will directly help in designing and managing their breeding habitats.

Here, we examined habitat selection by great Indian bustards in a semiarid multiple-use landscape, to demonstrate how to manage breeding reserves. Specifically, we asked: (1) Do these birds select different habitats at fine-grained scales (hereafter referred to as microhabitat or resource units) to fulfil their daily ecological needs, and what are the implications for resource selection studies that ignore these behavioral differences? (2) Does density/usage (number of birds per unit area) at larger grain sizes depend on the availability of complementary resource units at finer scales such that strategic insertion of missing resource units can promote greater patch usage? To this end, we collected microhabitat data from $100 \mathrm{~m}$ radius plots at locations used by great Indian bustards for foraging, day resting, night roosting, courting and nesting, along with available (random) locations. We developed resource selection functions (RSFs) for each behavior and a common RSF for all behaviors by testing ecological predictions with used vs. available habitat data using binomial generalized linear models (GLMs) in an information-theoretic framework (Manly et al. 2002). We compared inferences between behaviorally explicit and common RSFs, to answer the first question. For the second question, we classified random locations as 'suitable' or 'unsuitable' for a behavior based on fitted RSF values, and computed microhabitat diversity at a larger scale (transects) from the frequency of 'suitable' locations for various behaviors. Finally, we examined if the species' density in transects, estimated using distance sampling (Burnham et al. 1980), depended on microhabitat diversity, using GLM. 


\section{MATERIALS AND METHODS}

\subsection{Study area}

We conducted fieldwork from 2007 through 2011 in Abdasa tehsil (precinct) of Kachchh, Gujarat, India. This landscape harbors a small and declining population of great Indian bustards that uses a central contiguous patch of $175 \mathrm{~km}^{2}$ during the breeding season (summer: March-June, monsoon: July-October)
(Dutta 2012). The regional climate is semiarid with high temperature variations $\left(0-5^{\circ} \mathrm{C}\right.$ in January to $40-45^{\circ} \mathrm{C}$ in May) and scant rainfall (mean $384 \mathrm{~mm}$, range 78-888 mm during 2000-2010). Tropical thorn forest/scrub and grasslands (Champion \& Seth 1968) are grazed by free-ranging livestock, and are interspersed with Sorghum bicolor, Pennisetum glaucum, Arachis hypogaea and Gossypium spp. cultivation (Fig. 1). Recently, cultivation has expanded with more frequent tilling and year-round cropping, lead-

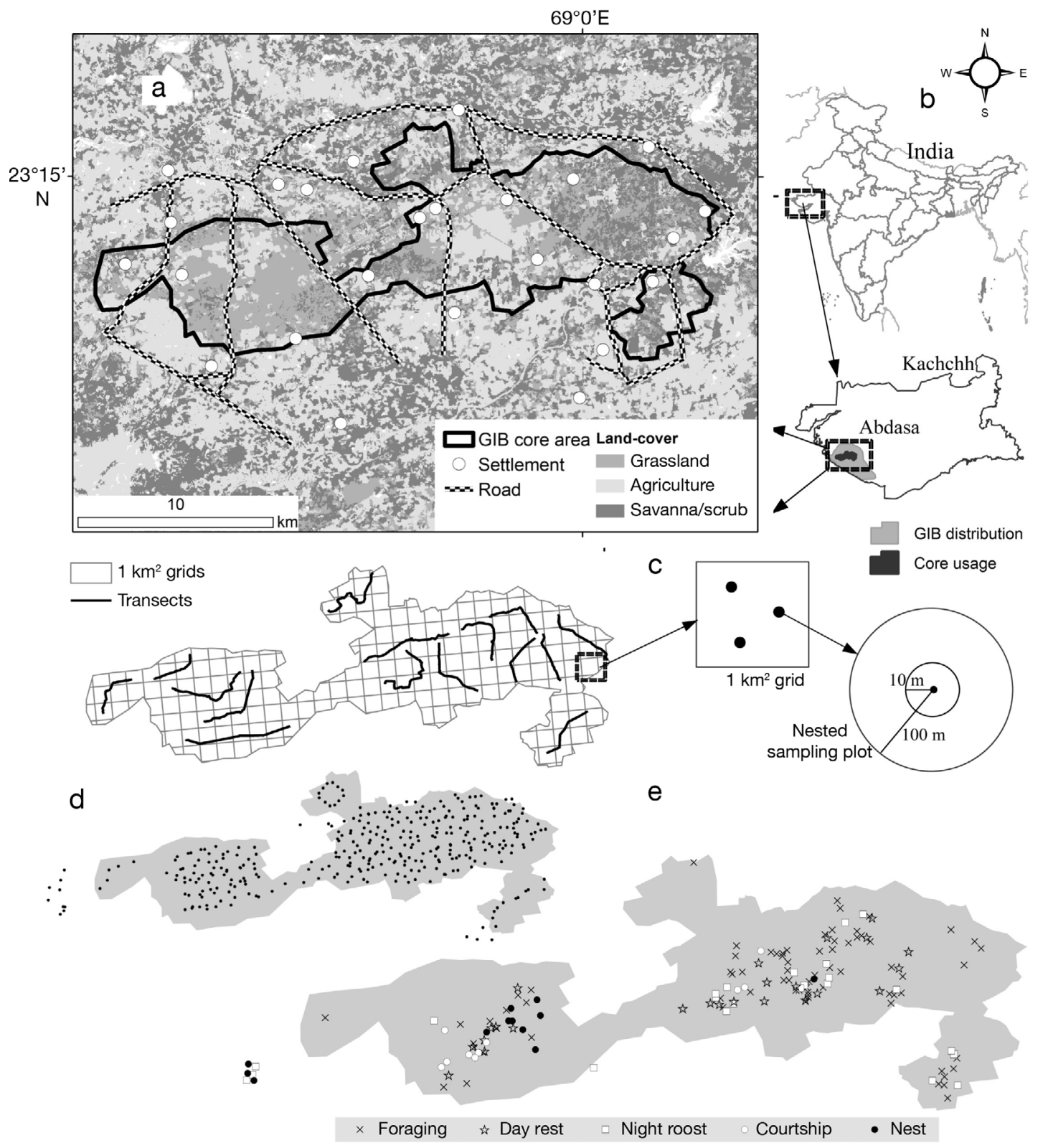

Fig. 1. Study area and sampling design. (a) Prime breeding habitat of great Indian bustard (GIB), showing major land covers. (b) Location of study area in Abdasa, Kachchh, India. (c) Sampling scheme for measuring bird usage and habitat variables.

(d) Distribution of random locations. (e) Locations used by GIB for foraging, resting, roosting, courting and nesting behaviors during 2007-2011 
ing to higher livestock dependence on remnant pastures - a scenario that typifies the range of great Indian bustards (Dutta \& Jhala 2014). The Lala Bustard Sanctuary $\left(2 \mathrm{~km}^{2}\right)$ and 2 enclosures near Naliya $\left(20 \mathrm{~km}^{2}\right)$ and Kunathia $\left(4 \mathrm{~km}^{2}\right)$ villages have been established here for bustard conservation.

\subsection{Data collection and analyses}

\subsubsection{Bird-habitat surveys}

We searched the study area on foot and on existing trails with a motorcycle (driver with a pillion observer, traveling at $<10 \mathrm{~km} \mathrm{~h}^{-1}$ ) from dawn through dusk with a break during the day (12:30-14:30 h, when bird activity ceased). We covered the area 6 to 10 times during the breeding season over 2 years (2008-2009). We observed bird behavior using $8 \times 42$ binoculars from suitable vantage points (at 200-500 m distance from the focal birds) that allowed an unobstructed view without altering their natural behavior. We recorded landmarks and projected locations with a GPS unit corresponding to the following behaviors: (1) foraging, where birds were intensively feeding or searching for food; (2) resting, where birds retired by sitting with the head drawn against the body for at least 20-30 min in the daytime; (3) roosting, where birds retired after sunset and ample fecal/feather deposits were recovered during the following morning indicating that birds had stayed at that spot overnight; (4) courtship, where males performed sexual displays from arenas, including territorial rituals; and (5) nesting, where females incubated eggs and egg-shells were subsequently retrieved. To increase sample size, we used nest information from surveys conducted by the State Forest Department around the same years as our study, and these data might represent nests of the same females. Similarly, courtship locations were obtained from different display arenas of the same males and over multiple years.

We visited 'used' locations after bird(s) moved away, and measured variables that could potentially influence habitat selection. Since most birds distinguish habitat based on structural characteristics (Cody 1985), we measured 10 variables depicting land cover and vegetation structure, 2 variables for food availability and 3 variables for human disturbances. Descriptions, measurements and postulated effects of these variables are provided in Table 1. We measured these variables in nested circular plots of $100 \mathrm{~m}$ radius (9 variables) and $10 \mathrm{~m}$ radius (6 variables). To characterize 'available' habitat, we systematically sampled the same variables at 2-3 random locations in each $1 \mathrm{~km}^{2}$ grid overlaid on the study area. Random locations were generated in ArcGIS, and 1 location was sampled per grid in a season. However, a small fraction $(<10 \%)$ of grids could not be sampled representatively and adequately due to logistic constraints. These data represented the general habitat, not the unused area, and was preferred because the rarity of birds would contaminate unused locations with pseudo-absences (Johnson et al. 2006).

\subsubsection{Fine-grained RSFs}

We described the habitat of foraging ( $\mathrm{n}=76$ locations), resting (24), roosting (24), courting (10) and nesting (12) locations, using box and whisker plots and descriptive statistics for straightforward interpretation of the species' requirements. Before further analysis, we transformed the data as follows. (1) Vegetation variables were $z$-standardized using their seasonal means and standard deviations, to remove rainfall-induced difference in their summer and monsoon measurements and the ensuing noise in habitat selection inferences that were not relevant to this study. (2) Synthetic factors were extracted from strongly correlated habitat variables using factor analysis (following Graham 2003), to reduce data dimensionality and to avoid multicollinearity.

Thereafter, we examined habitat selection from used and available locations (design I of Manly et al. 2002) using GLMs with logit link and binomial errors (McCullagh \& Nelder 1989). Since used and available locations were sampled independently without replacement, the RSF was proportional to the exponential function:

$$
e^{\beta_{0}+\beta_{1} x_{1}+\ldots+\beta_{k} x_{k}}
$$

where $x_{p}=1 \ldots k$ are habitat variables and $\beta_{p}=1 \ldots k$ are model parameters to be estimated (Manly et al. 2002). Here, GLM estimates the probability of a resource unit being used if it is sampled, as:

$$
\frac{\mathrm{e}^{\beta_{0}^{\prime}+\beta_{1} x_{1}+\ldots .+\beta_{k} x_{k}}}{1+\mathrm{e}^{\beta_{0}^{\prime}+\beta_{1} x_{1}+\ldots .+\beta_{k} x_{k}}}
$$

where the intercept $\beta^{\prime}{ }_{0}$ is modified from $\beta_{0}$ to include sampling probabilities of used and available units.

First, we modeled RSFs for 'general occurrence' by pooling used locations across all behaviors, to mimic the common approach of behaviorally simplistic habitat analysis. Since behavioral differences precluded hypotheses that were generalizable across behaviors, we used exploratory (all subsets) model 
Table 1. Collection of habitat variables from locations used by great Indian bustards and random locations along with their a priori predicted effects on resource selection. Variables were measured at different scales (coarse: $100 \mathrm{~m}$ and fine: $10 \mathrm{~m}$ radii) to strike a balance between (i) the mobility of birds: great Indian bustards can cover $1900 \mathrm{~m} \mathrm{~h}^{-1}$ (S. Dutta unpubl. data); and Gray et al. (2007) used $50 \mathrm{~m}$ radius plots for the related, but smaller, Bengal florican; (ii) inherent scale disparity among variables: land cover is homogeneous and therefore measurable at a larger grain size than vegetation structure; and (iii) practicality of sampling: fruiting intensity can be assessed over larger area than insect abundance. Sources: (1) Johnsgard (1991), (2) Wolff et al. (2001), (3) Rahmani (1989), (4) S. Dutta pers. obs., (5) Magana et al. (2010), (6) Stephens \& Krebs (1986), (7) Dutta (2012), (8) Hilbert et al. (1981), (9) Lavee (1988), (10) Osborne et al. (2001), (11) Dutta et al. (2011)

\begin{tabular}{|c|c|c|c|}
\hline Feature & Variables & Measurement and processing & A priori hypotheses and predictions \\
\hline Land cover & $\begin{array}{c}\text { Grassland } \\
\text { Scrubland } \\
\text { Agriculture } \\
\text { Agro-veg mix }\end{array}$ & $\begin{array}{l}\text { We recorded the dominant land cover } \\
\text { in } 100 \text { m radius of a location by ocular } \\
\text { assessment. Co-dominance of grass/ } \\
\text { scrub and agriculture was recorded as } \\
\text { 'agro-veg mix' }\end{array}$ & $\begin{array}{l}\text { Bustards evolved in open habitats, and } \\
\text { would generally prefer grassland (1); but } \\
\text { moderately human-altered land uses offer } \\
\text { higher food diversity (2) and can be } \\
\text { selected for foraging }\end{array}$ \\
\hline $\begin{array}{l}\text { Vegetation } \\
\text { characteristics } \\
\text { (coarse grain) }\end{array}$ & $\begin{array}{l}\text { Grass height } \\
\text { Grass cover } \\
\text { Shrub height } \\
\text { Shrub cover }\end{array}$ & $\begin{array}{l}\text { We recorded vegetation characteristics } \\
\text { on a } 5 \text {-point scale by classifying their } \\
\text { range at (a) } 5,20,40,70,110 \mathrm{~cm} \text { (grass } \\
\text { height); (b) 10,20,40,60,100\% (grass } \\
\text { cover); (c) } 0.5,1.0,2.0,3.0,5.0 \mathrm{~m} \text { (shrub } \\
\text { height); and (d) 5, 15,25,40,70\% (shrub } \\
\text { cover), based on ocular assessment in a } \\
100 \mathrm{~m} \text { radius around a location }\end{array}$ & $\begin{array}{l}\text { Because of contrasting preferences of } \\
\text { concealment and visibility for different } \\
\text { ecological needs, sparse vegetation will be } \\
\text { selected for roosting to enhance surveil- } \\
\text { lance and reduce ambush predation, and } \\
\text { for courtship to allow transmission of } \\
\text { sexual advertisement; moderately tall, } \\
\text { dense vegetation for resting to reduce } \\
\text { thermal stress and for nesting to provide }\end{array}$ \\
\hline $\begin{array}{l}\text { Vegetation } \\
\text { stratification } \\
\text { (fine grain) } \\
\text { Ves }\end{array}$ & $\begin{array}{l}\text { Bare ground \% } \\
\text { Vegetation } \\
(<25 \mathrm{~cm}) \% \\
\text { Vegetation } \\
(25-50 \mathrm{~cm}) \% \\
\text { Vegetation } \\
(50-100 \mathrm{~cm}) \% \\
\text { getation }(>1 \mathrm{~m}) \%\end{array}$ & $\begin{array}{l}\text { We measured vegetation stratification in } \\
\text { a } 10 \mathrm{~m} \text { radius around a location as the } \\
\text { proportion of } 10 \text { vertical hits of a } 1 \mathrm{~m} \\
\text { calibrated pole where the ground } \\
\text { vegetation cover crossed } 25,50 \text { and } \\
100 \mathrm{~cm} \text { marks }\end{array}$ & $\begin{array}{l}\text { concealment; and intermediate vegetation } \\
\text { to optimize food abundance and detection, } \\
\text { for foraging }(3,4,5) \text {. Tall, thorny shrubs } \\
\text { may be avoided because of hindrance to } \\
\text { visibility and movements }(3,4)\end{array}$ \\
\hline $\begin{array}{l}\text { Resource } \\
\text { availability }\end{array}$ & $\begin{array}{c}\text { Insects } \\
\text { Fruit }\end{array}$ & $\begin{array}{l}\text { We counted insects in a } 20 \times 2 \mathrm{~m}^{2} \text { strip } \\
\text { in } 10 \mathrm{~m} \text { radius around a location and } \\
\text { indexed fruit availability as } 0 \text { (low) to } \\
4 \text { (high) based on fruiting shrubs/trees in } \\
\text { a } 100 \mathrm{~m} \text { radius around a location }\end{array}$ & $\begin{array}{l}\text { While birds may track food resources (6), } \\
\text { the patchier food type (fruits rather than } \\
\text { insects) can exert greater influence on the } \\
\text { choice of foraging site (4) }\end{array}$ \\
\hline $\begin{array}{l}\text { Key shrub } \\
\text { dominance }\end{array}$ & $\begin{array}{l}\text { Zizyphus } \\
\text { Prosopis }\end{array}$ & $\begin{array}{l}\text { We ranked the dominance of these shrubs } \\
\text { in a } 100 \mathrm{~m} \text { radius around a location as } 0 \\
\text { (absent) to } 3 \text { (most abundant) }\end{array}$ & $\begin{array}{l}Z \text {. nummularia, a stunted shrub that great } \\
\text { Indian bustards frequently feed on (win- } \\
\text { ter-summer) }(3,4,7) \text { can attract foraging } \\
\text { use, whereas } P \text {. juliflora, an invasive exotic } \\
\text { shrub that forms dense thickets, obstruct- } \\
\text { ing visibility and facilitating predators, will } \\
\text { be generally avoided (4) }\end{array}$ \\
\hline \multirow[t]{2}{*}{$\begin{array}{l}\text { Anthropogenic } \\
\text { disturbances }\end{array}$} & $\begin{array}{l}\text { Grazing } \\
\text { pressure }\end{array}$ & $\begin{array}{l}\text { We quantified grazing pressure using } \\
3 \text { indices: (1) visible impacts of grazing/ } \\
\text { browsing and trampling (MacDonald et al. } \\
\text { 1998) in a } 100 \mathrm{~m} \text { radius around a location, } \\
\text { and counts of (2) pellets/dung and (3) } \\
\text { tracks along a } 20 \text { m transect at a location. } \\
\text { We scored these indices as } 0 \text { (low) to } 4 \\
\text { (high) and averaged these values into a } \\
\text { composite score that was more compre- } \\
\text { hensive than any single measure }\end{array}$ & $\begin{array}{l}\text { Following the grazing optimization concept } \\
\text { (8), we postulated that intermediate } \\
\text { grazing pressure can favor foraging use by } \\
\text { optimizing vegetation productivity and } \\
\text { making dung beetles (an important food) } \\
\text { transiently available. However, human } \\
\text { disturbances associated with grazing can } \\
\text { deter nesting use (9) }\end{array}$ \\
\hline & $\begin{array}{l}\text { Distance to } \\
\text { village } \\
\text { Distance } \\
\text { to road }\end{array}$ & $\begin{array}{l}\text { We recorded the distance of a location to } \\
\text { the nearest village and metal road from } \\
\text { field-digitized maps in ArcGIS } 9.2\end{array}$ & $\begin{array}{l}\text { While birds may generally avoid human } \\
\text { artifacts to reduce mortality risks }(10,11) \text {, } \\
\text { such a response can be particularly pro- } \\
\text { nounced during resting/roosting, when } \\
\text { birds are stationary and more vulnerable to } \\
\text { attacks }\end{array}$ \\
\hline
\end{tabular}


building for general occurrence. Next, we developed an RSF for each behavior by building candidate models corresponding to alternative hypotheses (Table 1). The global models included variables with greatest $a$ priori importance, to ensure $\geq 5$ 'used' data points per estimated effect (following Vittinghoff \& McCulloch 2007). We examined the goodness of fit (GOF) and variance inflation factors of the global models (Quinn \& Keough 2002). On obtaining satisfactory diagnoses, we compared candidate models in an information theoretic framework (Burnham \& Anderson 2002). We used the average (when competing models were $<2 \triangle \mathrm{AICC}$ units apart, where AICc is Akaike's information criterion corrected for small sample size) or the least AICc model in its exponent form as the RSF (Boyce 2006). We interpreted behavioral differences in RSFs based on the direction, magnitude and precision of model parameters. To evaluate the reliability of inferences, we reiterated the RSF modeling for each behavior over 10 runs with different subsets of available locations (50\% locations chosen at random without replacement in a run). We used the mean and CV of variable effect sizes across bootstrapped models, to examine the variability among individual RSF runs and for robust prediction of microhabitat suitability. Despite subsampling the data, sampling ratios were large (5-10 available locations per used location) for most behaviors, which has been shown to reduce inference bias (Baasch et al. 2010, Nad'o \& Kaňuch 2018). We conducted these analyses in R v 2.13.0 (R Core Team 2013) (R script data code is available in Supplement 1 at www.intres.com/articles/suppl/n045p055_supp/).

\subsubsection{Coarse-grained space use}

We estimated great Indian bustard density (number per area) along line transects using distance sampling (Burnham et al. 1980), as a measure of their usage at the coarse grain. We surveyed 15 transects of average $4 \pm 0.7$ (SD) $\mathrm{km}$ length and $1 \mathrm{~km}$ width on either side, on a slow-moving motorcycle with a pillion observer during the prime bird activity period (07:00-11:00 and 17:00-19:30 h, Rahmani 1989). We resurveyed each transect 4 times during the breeding season for 3 years (2008-2010), resulting in an average of $12 \pm 2$ temporal replicates per transect. This grain size (average $8 \mathrm{~km}^{2}$ ) offered varying degrees of structural complexity that could influence habitat usage, and matched the daily range of this species $\left(2.6 \pm 5.0 \mathrm{~km}^{2}\right.$ based on 1 tagged bird, authors' unpubl. data). Transects were placed on available dirt trails with no bias towards high-usage areas. We modeled perpendicular distances of bird sightings from the transect using hazard rate and half-normal detection functions, and selected the best model using AICc (Akaike 1974) and GOF tests in the program DISTANCE v 5.2 (Thomas et al. 2010). We estimated a common detection probability since visibility did not vary much across the study area, and applied it to convert encounter rates at the transect level into density estimates. Distance sampling has been applied to other bustards as well (Tourenq et al. 2005), and violations of its assumptions will not affect the relative space usage, which was the parameter of interest.

\subsubsection{Resource complementarity and congruence across scales}

Fitted RSF values predicted the relative probability of selecting random locations for a behavior (Manly et al. 2002). Subsequently, we classified random locations with RSF values exceeding the first quartile RSF value of used locations (implying relatively high chance of selection) as suitable resource units for that behavior. For robust prediction, we averaged the location's predicted state (suitable/unsuitable) across 10 bootstrapped RSFs (see Section 2.2.2 and Tables S1 to S3 in Supplement 2 at www.int-res.com/articles/ suppl/n045p055_supp/). We also identified resource units for general occurrence in a similar way that reflected simplistic (behaviorally inexplicit) inferences on habitat selection.

Next, we examined if resource characteristics, and hence, suitability of random locations, were similar across behaviors and general occurrence. We tested this postulate using scatter plots and Pearson's correlation analysis (Quinn \& Keough 2002) on pairs of predicted RSF values (relative suitability of locations) for various behaviors and general occurrence.

Finally, we examined if availability and complementarity of resource units influenced usage at the coarse grain. For this, we quantified 'resource availability' (RA) in $\sim 8 \mathrm{~km}^{2}$ transect areas, as the proportion of random locations that were suitable for any behavior (hereafter, useable resource units). We quantified 'resource complementarity' (RC) as the product of the frequency of useable resource units in the transect area and the exponent form of the Shannon-Wiener index, computed from proportions of suitable resource units for various behaviors. This index served as a surrogate for the effective number of complementary resources (Jost 2006) and obtained higher values for transect areas with greater availability of diverse re- 
source units. We modeled great Indian bustard density at transects using Gaussian GLMs to examine the effects of RA and RC against the null model (constant density). We used AICC and $\mathrm{R}^{2}$ statistics to compare these models (Quinn \& Keough 2002).

\section{RESULTS}

\subsection{Microhabitat characteristics}

Great Indian bustard microhabitats differed between behaviors and from available locations in several ways (Fig. 2; Table S4 in Supplement 3 at www. int-res.com/articles/suppl/n045p055_supp/). Available land cover comprised grassland $>$ scrub $\approx$ agro- vegetation mixture $>$ agriculture. Birds used grasslands for nesting and courtship, and grassland or agro-vegetation mixture for foraging; whereas, use of agricultural land was minimal. Available vegetation was structurally dominated by bare ground $\approx$ short $(<25 \mathrm{~cm})$ sward $>$ moderate $(25-50 \mathrm{~cm})$ sward $>$ tall (50-100 cm) sward. Birds used relatively tall sward for nesting, relatively short sward for courtship and roosting, and moderate sward for resting.

Since vegetation variables were collinear $(|\rho|>0.4$, see Table S5 in Supplement 3), they were summarized into 3 synthetic factors that cumulatively explained $64 \%$ variance in data. These factors represented gradients of: (1) openness to moderately tall and dense sward (hereafter, sward biomass factor), (2) short to tall herbaceous cover (hereafter, short vs. tall sward
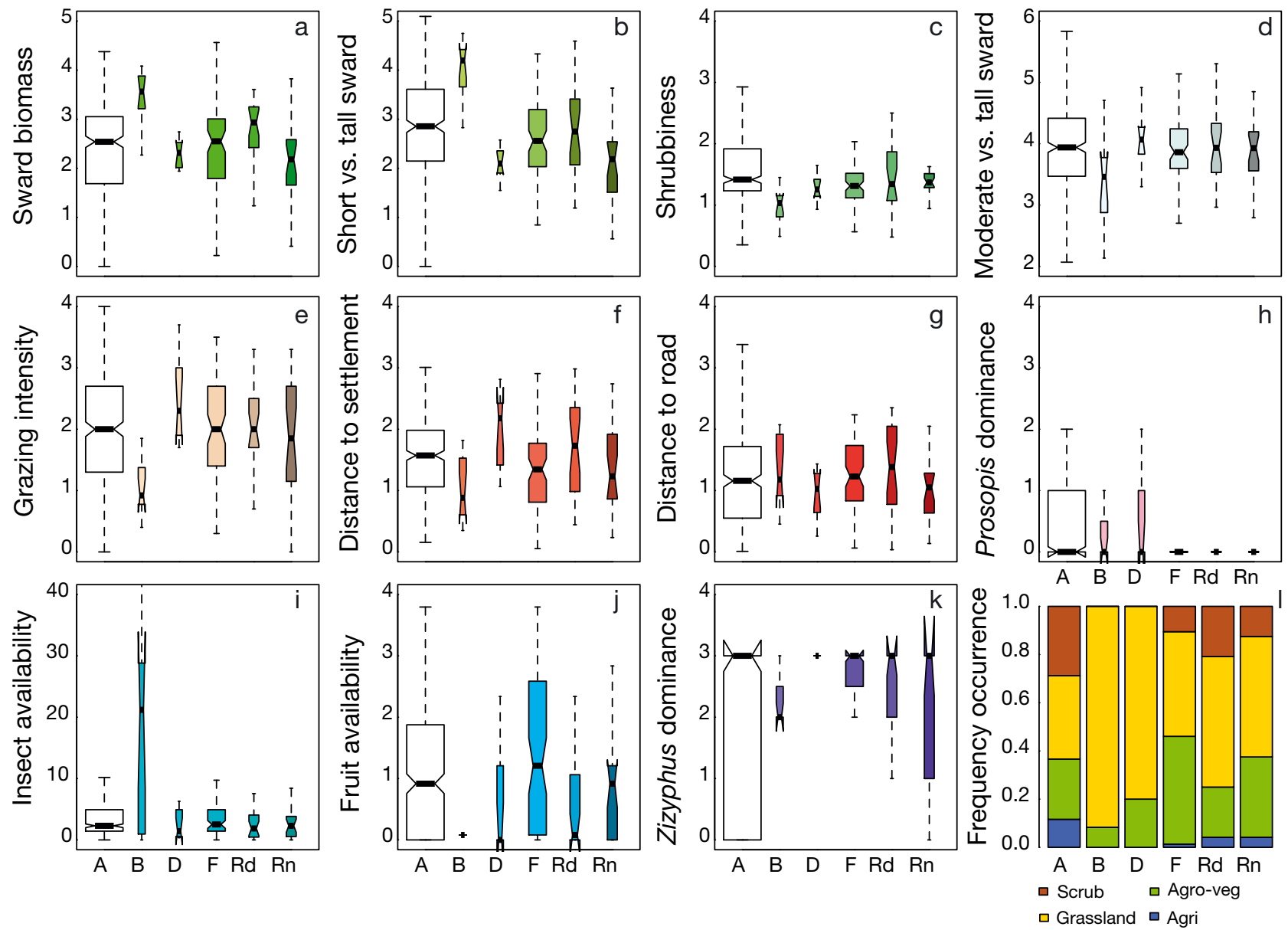

Fig. 2. Quartile distribution of microhabitat variables for great Indian bustards in Kachchh, India: (a) sward biomass; (b) short vs. tall sward; (c) shrubbiness (factors); (d) moderate vs. tall sward; (e) grazing intensity index; distances (km) to (f) nearest settlement and $(\mathrm{g})$ paved road; $(\mathrm{h})$ invasive Prosopis dominance, (i) insect count per $10 \mathrm{~m}$, (j) fruit availability, (k) native Zizyphus dominance, and (l) relative frequency (proportion) of land covers. 'Available' habitat is marked with A (open boxplots). 'Used' locations (solid boxplots) are as follows: B: breeding/nesting, D: courtship/display, F: foraging, Rd: day resting and Rn: night roosting. Notch represents median, box represents central $25-75 \%$ observations, whiskers represent extreme lower $(2.5-$ $25 \%$ ) and upper (75-97.5\%) observations. Thickness of boxplots reflects sample size, and non-overlapping notches indicate difference in medians of a variable 
factor) and (3) shrub biomass (hereafter, shrubbiness factor), respectively (Table S6 in Supplement 3).

\subsection{Behaviorally explicit RSFs}

Comparison between alternative hypotheses on foraging use showed that birds selected agro-vegetation mixture and grassland over agriculture, higher fruit abundance, Zizyphus (stunted fruiting shrubs), intermediate grazing intensity and relative proximity to settlements, but avoided Prosopis thickets (Tables 2 \& 3). Multi-model inference based on the top 3 hypotheses on day resting showed that birds selected relatively tall-dense sward while other variables lacked precise effects. However, we omitted resting RSFs from further analysis since the full model showed a poor fit to the data (Nagelkerke $\mathrm{R}^{2}=0.05$ ). Multi-model inference based on the top 3 hypotheses for night roosting showed that birds selected shorter sward and avoided Prosopis. For nesting use, the full model received maximum support and indicated selection for grassland, tall sward and higher insect abundance. For courtship use, the full model obtained maximum support and indicated selection for grassland, shorter sward and greater distance from settlements. Model bootstrapping with different subsets of random locations indicated that the above inferences were reasonably robust, since the effect sizes of important variables were estimated with $<20 \% \mathrm{CV}$ across model runs for foraging, roosting, courting and nesting behaviors (Table 3).

As evident from RSF model rankings and parameter estimates, factors influencing habitat selection and their effects varied between behaviors. Resource selection values of locations were weakly correlated between types of use ( $\mathrm{r}$ ranged from -0.04 [roosting $\times$ nesting] through 0.18 [foraging $\times$ roosting]; Fig. S1 in Supplement 3), indicating that a single microhabitat type is not suitable for all behaviors. Although $52 \pm$ $5 \%$ (95\% CI) of available locations were found to be useable, resource units for foraging were more prevalent $(37 \pm 5 \%)$ than for roosting $(26 \pm 5 \%)$, courtship $(20 \pm 4 \%)$ and nesting $(3 \pm 2 \%)$.

Our exploratory model building for RSFs of general occurrence (14 top models within $<2 \Delta$ AICc units) indicated that grassland and agro-vegetation mixture were selected over scrub and agriculture, Prosopis was avoided, and short sward was preferred over tall sward (Table 3). Effects of other habitat variables were imprecise. Resource selection values of locations for general occurrence were incongruent with those of specific behaviors ( $\mathrm{r}$ ranged from -0.06 [use $\times$ roosting] through 0.35 [use $\times$ foraging]; Fig. S1).

\subsection{Usage at coarse resolution}

Transect surveys of $917 \mathrm{~km}$ yielded 55 detections of great Indian bustards along 15 spatial replicates during the breeding season. A half-normal detection function with cosine adjustment best fitted the distance data (lowest AICC and GOF- $\chi^{2}=0.60$, df $=3$, $\mathrm{p}=0.90$ ). Effective strip width was estimated to be $231 \mathrm{~m}$ (95\% CI: 177-301 m). Bustard density was estimated to be $0.17(0.13-0.23)$ ind. $\mathrm{km}^{-2}$, indicating that 29 (22-39) birds used the area. Bird density varied substantially across transects (CV 102\%), ranging between 0 and 0.65 ind. $\mathrm{km}^{-2}$. Density across transects ( $\mathrm{n}=12 ; 3$ transects dropped due to inadequate habitat data) was best explained by the availability of complementary resources (RC: Akaike weight $W=0.65, \mathrm{R}^{2}=0.43$ ), showing a positive relationship between the 2 variables $(\beta=0.74 \pm 0.24 \mathrm{SE}$ ) (Fig. 3; Table S7 in Supplement 3). Residual plot diagnosis indicated acceptable fit of this model to the data (Fig. S2 in Supplement 3).

\section{DISCUSSION}

Bustards are declining globally, with nearly twothirds of the taxa listed as Threatened or Near Threatened (BirdLife International 2018). Their conservation is a global challenge and necessitates comprehensive understanding of habitat requirements. The great Indian bustard population in Kachchh has declined since the study to a current total of about 5 birds (D. Gadhvi unpubl. data). Their decline is largely attributed to collision with overhead powerlines and habitat alteration. Although biotelemetry can provide robust insights into resource selection, research funding and permit restrictions have often precluded tagging of a large sample of individuals that is necessary for such inferences. This makes direct observations at the population level the most feasible available approach for many species.

\subsection{Effects of habitat variables}

Great Indian bustards selected grassland and avoided agricultural land. Selectivity of grasslands was particularly strong for courtship and nesting activities. Bustards prefer flat, undisturbed grasslands for sexual advertisement and nesting (Osborne et al. 2001), and this postulate was corroborated by our finding. India's grasslands are facing agricultural expansion and intensification, involving reduced fallow 
Table 2. Ranking of alternative hypotheses on (a) foraging, (b) resting, (c) roosting, (d) nesting and (e) courtship resource selections of great Indian bustards in Kachchh, India. Binomial generalized linear models fitted on variables: land cover (hab) or grassland (hab-grl) vs. other land covers, sward biomass (swd-bio), tall vs. short sward (tl-swd) and shrubbiness (shrb) factors, insect (ins) and fruit (frt) availability, Prosopis (pro) and Zizyphus (ziz) dominance, grazing intensity (grz), distance to settlement (dst-set) and distance to road (dst-rd). Quadratic effects of some variables (e.g. sward biomass swd-bio ${ }^{2}$ and grazing intensity $\mathrm{grz}^{2}$ ) were included in models to test predictions that immediate values of these variables might be selected. Summary statistics include Akaike weight $(W)$, Akaike's information criterion corrected for small sample size (AICc), difference of AICc from the lowest AICc value $(\triangle \mathrm{AICc})$, deviance (-2logL) and model parameters $(K)$

\begin{tabular}{|c|c|c|c|c|c|}
\hline & $W$ & $\triangle \mathrm{AICC}$ & $\mathrm{AICc}$ & $-2 \log L$ & $K$ \\
\hline \multicolumn{6}{|l|}{ (a) Candidate models for foraging use } \\
\hline hab + pro + ziz + frt + grz + grz $^{2}+$ dst-set & 0.38 & 0.00 & 279.76 & 238.86 & 10 \\
\hline hab + shrb + ziz + frt + grz + grz $^{2}+$ dst-set & 0.14 & 2.00 & 281.76 & 240.86 & 10 \\
\hline hab + pro + ziz + frt + grz + grz $^{2}$ & 0.14 & 2.02 & 281.78 & 245.05 & 9 \\
\hline hab + swd-bio + swd-bio ${ }^{2}+$ pro + ziz + frt + grz + grz $^{2}+$ dst-set & 0.07 & 3.37 & 283.13 & 233.84 & 12 \\
\hline 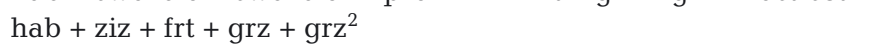 & 0.05 & 4.14 & 283.90 & 251.32 & 8 \\
\hline hab + swd-bio + swd-bio ${ }^{2}+$ pro + ziz + frt + dst-set & 0.04 & 4.32 & 284.08 & 243.18 & 10 \\
\hline hab + shrb + ziz + frt + grz + grz $^{2}$ & 0.04 & 4.46 & 284.22 & 247.49 & 9 \\
\hline hab + swd-bio + swd-bio + pro + ziz + frt + grz + grz $^{2}$ & 0.03 & 5.06 & 284.82 & 239.74 & 11 \\
\hline hab + swd-bio + swd-bio ${ }^{2}+$ shrb + ziz + frt + grz + grz ${ }^{2}+$ dst-set & 0.03 & 5.31 & 285.08 & 235.79 & 12 \\
\hline hab + ziz + frt & 0.02 & 6.13 & 285.89 & 261.55 & 6 \\
\hline hab + swd-bio + swd-bio ${ }^{2}+$ shrb + ziz + frt & 0.00 & 8.94 & 288.70 & 251.97 & 9 \\
\hline $\begin{array}{l}\text { hab + swd-bio }+ \text { swd-bio }{ }^{2}+\text { tl-swd }+ \text { shrb }+ \text { pro }+ \text { ziz }+ \text { frt }+ \text { ins }+ \\
\text { grz }+ \text { grz }^{2}+\text { dst-set }+ \text { dst-rd }\end{array}$ & 0.00 & 9.74 & 289.50 & 223.22 & 16 \\
\hline swd-bio + swd-bio ${ }^{2}+$ pro + ziz + frt & 0.00 & 10.17 & 289.94 & 265.60 & 6 \\
\hline hab + swd-bio + swd-bio $^{2}+$ pro & 0.00 & 13.35 & 293.11 & 264.66 & 7 \\
\hline hab & 0.00 & 16.08 & 295.84 & 279.68 & 4 \\
\hline $\mathrm{ziz}+\mathrm{frt}+\mathrm{ins}$ & 0.00 & 19.22 & 298.98 & 282.82 & 4 \\
\hline frt & 0.00 & 25.52 & 305.29 & 297.24 & 2 \\
\hline pro & 0.00 & 25.88 & 305.64 & 297.60 & 2 \\
\hline$g r z+g r z^{2}$ & 0.00 & 29.83 & 309.60 & 297.50 & 3 \\
\hline swd-bio + swd-bio ${ }^{2}$ & 0.00 & 30.79 & 310.55 & 298.45 & 3 \\
\hline dst-set & 0.00 & 31.01 & 310.77 & 302.73 & 2 \\
\hline null & 0.00 & 33.65 & 313.41 & 309.39 & 1 \\
\hline ins & 0.00 & 34.78 & 314.54 & 306.50 & 2 \\
\hline swd-bio & 0.00 & 35.18 & 314.94 & 306.90 & 2 \\
\hline grz & 0.00 & 35.36 & 315.12 & 307.07 & 2 \\
\hline \multicolumn{6}{|l|}{ (b) Candidate models for resting use } \\
\hline swd-bio & 0.31 & 0.00 & 147.47 & 139.41 & 2 \\
\hline swd-bio + dst-set & 0.16 & 1.29 & 148.76 & 136.64 & 3 \\
\hline swd-bio + shrb & 0.16 & 1.37 & 148.83 & 136.71 & 3 \\
\hline null & 0.10 & 2.34 & 149.80 & 145.78 & 1 \\
\hline swd-bio + shrb + dst-set & 0.08 & 2.63 & 150.10 & 133.90 & 4 \\
\hline shrb & 0.06 & 3.41 & 150.87 & 142.81 & 2 \\
\hline dst-set & 0.05 & 3.54 & 151.01 & 142.95 & 2 \\
\hline \multicolumn{6}{|l|}{ (c) Candidate models for roosting use } \\
\hline swd-bio + tl-swd + pro & 0.32 & 0 & 129.47 & 113.27 & 4 \\
\hline tl-swd + pro & 0.31 & 0.09 & 129.57 & 117.45 & 3 \\
\hline swd-bio + tl-swd + pro + dst-set & 0.29 & 0.21 & 129.69 & 109.38 & 5 \\
\hline hab + swd-bio + tl-swd + pro & 0.05 & 3.69 & 133.17 & 104.59 & 7 \\
\hline hab + swd-bio + tl-swd + pro + dst-set & 0.03 & 4.52 & 133.99 & 101.25 & 8 \\
\hline tl-swd & 0 & 11.82 & 141.3 & 133.24 & 2 \\
\hline swd-bio + tl-swd + dst-set & 0 & 12.07 & 141.54 & 125.34 & 4 \\
\hline pro & 0 & 12.19 & 141.67 & 133.61 & 2 \\
\hline null & 0 & 20.33 & 149.8 & 145.78 & 1 \\
\hline dst-set & 0 & 21.18 & 150.66 & 142.6 & 2 \\
\hline hab & 0 & 21.31 & 150.78 & 134.58 & 4 \\
\hline swd-bio & 0 & 21.82 & 151.29 & 143.23 & 2 \\
\hline
\end{tabular}


Table 2 (continued)

\begin{tabular}{|c|c|c|c|c|c|}
\hline & $W$ & $\Delta \mathrm{AICc}$ & $\mathrm{AICc}$ & $-2 \log L$ & $K$ \\
\hline \multicolumn{6}{|c|}{ (d) Candidate models for nesting use } \\
\hline hab-grl + tl-swd + ins & 0.98 & 0.00 & 38.49 & 22.27 & 4 \\
\hline tl-swd + ins & 0.02 & 7.90 & 46.39 & 34.26 & 3 \\
\hline hab-grl + ins & 0.00 & 13.99 & 52.48 & 40.36 & 3 \\
\hline hab-grl + tl-swd & 0.00 & 24.47 & 62.96 & 50.83 & 3 \\
\hline ins & 0.00 & 27.68 & 66.17 & 58.10 & 2 \\
\hline tl-swd & 0.00 & 38.84 & 77.33 & 69.27 & 2 \\
\hline hab-grl & 0.00 & 39.32 & 77.81 & 69.75 & 2 \\
\hline null & 0.00 & 53.31 & 91.80 & 87.78 & 1 \\
\hline \multicolumn{6}{|c|}{ (e) Candidate models for courtship use } \\
\hline hab-grl + tl-swd + dst-set & 0.71 & 0.00 & 67.02 & 50.80 & 4 \\
\hline hab-grl + dst-set & 0.19 & 2.67 & 69.69 & 57.56 & 3 \\
\hline hab-grl + tl-swd & 0.07 & 4.66 & 71.68 & 59.56 & 3 \\
\hline hab-grl & 0.02 & 7.35 & 74.37 & 66.30 & 2 \\
\hline tl-swd + dst-set & 0.01 & 7.99 & 75.01 & 62.88 & 3 \\
\hline tl-swd & 0.00 & 10.70 & 77.72 & 69.66 & 2 \\
\hline null & 0.00 & 13.35 & 80.37 & 76.35 & 1 \\
\hline
\end{tabular}

Table 3. Resource selection functions for foraging, resting, roosting, nesting, courtship and general occurrence of great Indian bustards in Kachchh, India: (a) estimated effects $\beta$ (SE) of habitat variables based on a random subset of available locations, (b) bootstrapped mean (CV) effects of same variables from model iterations with different subsets of available locations. Blank cells indicate variable effects that were either not tested or not selected in the top/average model. Squared terms indicate potential quadratic effects that were tested since birds might select intermediate values of some variables for particular behaviors.

$\Sigma W$ : summed Akaike weight of variables across models explaining general occurrence

\begin{tabular}{|c|c|c|c|c|c|c|c|c|}
\hline $\begin{array}{l}\text { (a) } \\
\text { Features }\end{array}$ & Variables & Foraging & Resting & Roosting & Nesting & Courtship & Occurrence & $\Sigma W$ \\
\hline Land cover & $\begin{array}{l}\text { Agro-vegetation } \\
\text { Grassland } \\
\text { Scrubland }\end{array}$ & $\begin{array}{l}2.33(1.09) \\
2.27(1.09) \\
1.48(1.14)\end{array}$ & & & $3.47(1.45)$ & $2.40(0.87)$ & $\begin{array}{l}0.31(0.11) \\
0.38(0.11) \\
0.12(0.12)\end{array}$ & $\begin{array}{l}1 \\
1 \\
1\end{array}$ \\
\hline $\begin{array}{l}\text { Vegetation } \\
\text { structure }\end{array}$ & $\begin{array}{c}\text { Sward biomass } \\
\text { Sward biomass }{ }^{2} \\
\text { Tall vs. short sward } \\
\text { Shrubbiness }\end{array}$ & & $\begin{array}{r}0.46(0.24) \\
-0.18(0.24)\end{array}$ & $\begin{array}{l}-0.40(0.28) \\
-0.97(0.28)\end{array}$ & $2.33(0.82)$ & $-0.93(0.47)$ & $\begin{array}{l}0.01(0.02) \\
-0.002(0.005) \\
-0.05(0.03)\end{array}$ & $\begin{array}{l}0.05 \\
0.05 \\
0.95\end{array}$ \\
\hline $\begin{array}{l}\text { Shrub } \\
\text { dominance }\end{array}$ & $\begin{array}{l}\text { Prosopis } \\
\text { Zizyphus }\end{array}$ & $\begin{array}{r}-0.40(0.23) \\
0.36(0.15)\end{array}$ & & $-1.63(0.78)$ & & & $\begin{array}{r}-0.07(0.03) \\
0.03(0.03)\end{array}$ & $\begin{array}{c}1 \\
0.76\end{array}$ \\
\hline $\begin{array}{l}\text { Food } \\
\quad \text { resources }\end{array}$ & $\begin{array}{l}\text { Fruit availability } \\
\text { Insect availability }\end{array}$ & $0.34(0.14)$ & & & $0.22(0.06)$ & & $0.04(0.03)$ & 0.81 \\
\hline $\begin{array}{l}\text { Human } \\
\text { distur- } \\
\text { bances }\end{array}$ & $\begin{array}{l}\text { Grazing intensity } \\
\text { Grazing intensity }^{2} \\
\text { Dist. to settlement }\end{array}$ & $\begin{array}{r}1.97(0.91) \\
-0.50(0.22) \\
-0.49(0.24)\end{array}$ & $0.29(0.33)$ & $-0.51(0.38)$ & & $1.61(0.67)$ & $\begin{array}{r}0.03(0.06) \\
-0.02(0.02) \\
-0.01(0.02)\end{array}$ & $\begin{array}{l}0.35 \\
0.68 \\
0.41\end{array}$ \\
\hline $\begin{array}{l}\text { (b) } \\
\text { Features }\end{array}$ & Variables & Foraging & & Roosting & Nesting & Courtship & & \\
\hline Land cover & $\begin{array}{l}\text { Agro-vegetation } \\
\text { Grassland } \\
\text { Scrubland }\end{array}$ & $\begin{array}{l}2.41(0.13) \\
2.2(0.15) \\
1.26(0.26)\end{array}$ & & $\begin{array}{c}1(0.37) \\
0.79(0.3) \\
-0.54(0.71)\end{array}$ & $3.03(0.15)$ & $2.3(0.09)$ & & \\
\hline $\begin{array}{l}\text { Vegetation } \\
\text { structure }\end{array}$ & $\begin{array}{c}\text { Sward biomass } \\
\text { Sward biomass }{ }^{2} \\
\text { Tall vs. short sward } \\
\text { Shrubbiness }\end{array}$ & & & $\begin{array}{l}-0.47(0.2) \\
-1.03(0.12)\end{array}$ & $2.47(0.28)$ & $-0.84(0.17)$ & & \\
\hline $\begin{array}{l}\text { Shrub } \\
\text { dominance }\end{array}$ & $\begin{array}{l}\text { Prosopis } \\
\text { Zizyphus }\end{array}$ & $\begin{array}{r}-0.45(0.17) \\
0.46(0.11)\end{array}$ & & $-1.71(0.08)$ & & & & \\
\hline $\begin{array}{l}\text { Food } \\
\quad \text { resources }\end{array}$ & $\begin{array}{l}\text { Fruit availability } \\
\text { Insect availability }\end{array}$ & $0.33(0.19)$ & & & $0.11(0.75)$ & & & \\
\hline $\begin{array}{l}\text { Human } \\
\text { distur- } \\
\text { bances }\end{array}$ & $\begin{array}{l}\text { Grazing intensity } \\
\text { Grazing intensity } \\
\text { Dist. to settlement }\end{array}$ & $\begin{array}{r}2.02(0.18) \\
-0.49(0.16) \\
-0.61(0.15)\end{array}$ & & $-0.52(0.24)$ & & $1.37(0.15)$ & & \\
\hline
\end{tabular}




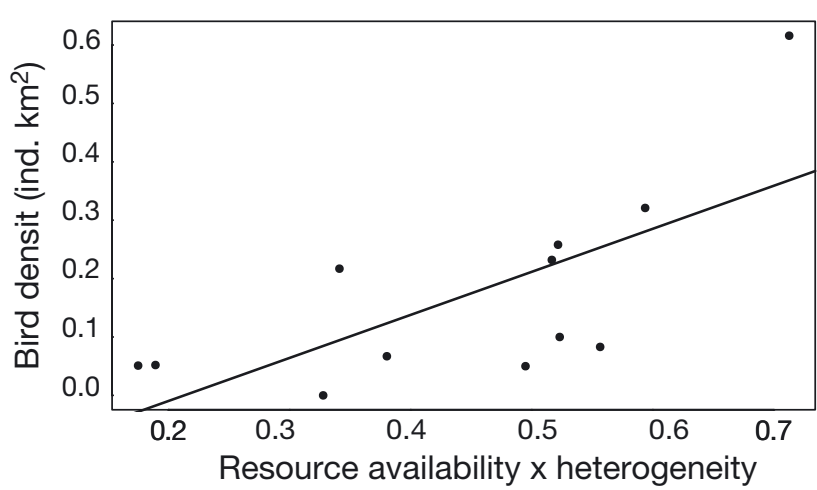

Fig. 3. Relationship between great Indian bustard density (representing coarse-grained use intensity) and availability of complementary resources along transects in Kachchh, India

periods, mechanized farming, inorganic pesticides, fertilizers and groundwater irrigation that are unfavorable for breeding bustards, much like their global counterparts (Dutta et al. 2013). However, the species also selected seasonal croplands interspersed within grassland/scrub (agro-vegetation mixture) for foraging. Bustards are generalist feeders (Lane et al. 1999), and great Indian bustards feed on insects, fruits, harvested crops and plant matter (Dutta 2012). Foraging birds might benefit from the structural heterogeneity of agro-vegetation mixture that provides a higher diversity and/or abundance of food items encompassing natural and agricultural subsets (Lane et al. 2001). Wolff et al. (2001) reported relatively higher density of little bustards Tetrax tetrax in mixed zones of steppe and extensive farms, and proposed that their abundance increased as natural grasslands were replaced by extensive agriculture, but decreased with intensification of farming. Similarly, we infer that large-scale conversion of grasslands into intensive agriculture is detrimental, but low-intensity seasonal agriculture interspersed within grasslands is compatible with great Indian bustard conservation. Hence, regulating the expansion of agriculture and managing its spatial arrangement can benefit the species, as has been shown for the related lesser florican Sypheotides indicus (Dutta \& Jhala 2014). The Indian government may consider declaring priority landscapes as eco-sensitive zones for such land-use regulations (Dutta et al. 2011).

Great Indian bustards selected relatively less grazed areas for nesting and more grazed areas for courtship. Grazing intensity underpins vegetation structure in this landscape (Dutta \& Jhala 2014). High-intensity grazing promotes shorter vegetation that is preferred by displaying males for transmitting sexual signals over larger distances (Hingrat et al.
2008, Gray et al. 2009), while low-intensity grazing allows taller vegetation that provides concealment for nesting (Magana et al. 2010). Nesting females might also prefer low-intensity grazing to avoid disturbance caused by livestock herds and their guard dogs; incubating MacQueen's houbara bustards Chlamydotis macqueenii have been observed to temporarily leave nests when disturbed by livestock (Koshkin et al. 2016). Although Koshkin et al. (2014, 2016) found that density and nesting productivity of C. macqueenii were independent of moderate levels of sheep density in Kyzylkum desert, Uzbekistan, these studies did not capture the most extreme livestock densities $\left(>80 \mathrm{~km}^{-2}\right)$ that would resemble our study area (25 animal units or 100 sheep/goat equivalents $\mathrm{km}^{-2}$, see Dutta 2012). Similarly, high livestock density was considered as the major reason behind poor nesting success of C. macqueenii in Israel (Lavee 1988). However, habitat selection for other behaviors was unrelated to livestock grazing, indicating that this land use was compatible with non-nesting ecological requirements. These findings support the prescribed action of fencing relatively small $\left(<10 \mathrm{~km}^{2}\right)$ and known breeding sites to regulate grazing and improve recruitment (Dutta et al. 2013). Curbing grazing in relatively smaller areas safeguards non-breeding ecological needs and pastoral resources. Nevertheless, the availability of better forage inside enclosures compared to the heavily grazed surroundings results in occasional conflicts between pastoralists and wildlife managers. Such conflicts need to be pacified through participatory actions (e.g. community fodder farms) or incentives (e.g. subsidizing market fodder).

Great Indian bustards selected shorter shrub heights $(1.18 \pm 0.13 \mathrm{~m} 95 \% \mathrm{CI})$, even more so for nesting $(0.40 \pm 0.20 \mathrm{~m})$ and courtship $(0.95 \pm 0.39 \mathrm{~m})$, compared to available habitat $(1.72 \pm 0.12 \mathrm{~m})$. Bustards depend on long-distance visibility for antipredator vigilance and sexual advertisement, which is compromised in excessively shrubby environments. We found stronger avoidance of particular shrubs such as Prosopis juliflora than shrubbiness per se, as tall-dense Prosopis thickets disrupt mobility and vision more than other shrubs. Historically, Forest Departments have planted arid-semiarid landscapes with shrub/tree species including P. juliflora, Acacia tortilis, A. bivenosa and Glyricidium spp. (Dutta 2018). Our findings suggest that this practice is detrimental to great Indian bustards. However, small patches of stunted fruiting shrubs such as Zizyphus can increase food availability, and foraging birds preferred its presence (Dutta 2012). 
Avoidance of shrubby areas with poor visibility and preference of relatively tall sward $(<100 \mathrm{~cm})$ for concealment by nesting females corroborated the conclusion of Magana et al. (2010) that nest site selection was a trade-off between visibility and concealment in the related great bustards Otis tarda.

Insect availability was markedly higher at nesting sites. Greater insect abundance can be an indirect effect of preferring less grazed and relatively tall sward (Jerrentrup et al. 2014) for nesting. Alternatively, breeding females might prefer nesting in areas with greater insect abundance to meet dietary requirements during the critical incubation and chick-rearing periods when movement is restricted (Bretagnolle et al. 2011). We did not find such strong selection of invertebrate-rich areas for foraging use. This could be due to the availability of patchier food such as fruits and crops, which may have been more important than uniformly distributed invertebrates in foraging decisions. Conversely, foraging birds might respond to invertebrate abundance at a larger scale than our sampling frame; this needs to be examined in future studies. Courtship locations were relatively remote from settlements, as was also observed in the case of displaying $C$. undulata in Morocco (Hingrat et al. 2008), reinforcing our understanding that relatively undisturbed habitats are essential for courtship activity. Although nesting sites appeared closer to settlements, this was perhaps because nests were spatially clustered around an Air Force establishment, whose effects differed from that of villages. Although similar studies on other bustard species have shown avoidance of infrastructure (Van Heezik \& Seddon 1999, Sastre et al. 2009), we did not find a strong negative response to roads and settlements for most behaviors. This finding could be an artefact of the sampling scale, as the gradient of anthropogenic disturbances within the breeding habitat was probably too narrow to elicit such behavioral responses.

\subsection{Complementary resources and congruence between scales}

We found that great Indian bustards selected contrasting habitat characteristics for different activities that corroborated Rahmani's (1989) qualitative descriptions. Birds selected relatively taller sward for nesting, shorter sward for courting and roosting, and moderate-height sward for resting, thus partitioning the spectrum of herbaceous vegetation into 'subniches.' Such behavioral differences in microhabitat use has several consequences for resource selection analyses and conservation. Firstly, a common RSF based on pooled occurrence data may not identify resource characteristics that are critical to the species' conservation. Our behaviorally inexplicit model did not show any precise effect of vegetation structure, except for a slight selection of shorter sward, thus rendering a lopsided view of the species' requirements. If this model were used to inform habitat management, it would result in proliferation of short grasslands, leading to depletion of relatively tall swards, which are important for nesting in this landscape. Secondly, inferences from such pooled occurrence data would be biased towards easily detectable behaviors. Resource characteristics of less detectable yet critical behaviors such as nesting or roosting would be under-represented in occurrence data and in the subsequent inferences. In our study, resource selection value for general occurrence showed a weaker correlation with roosting (an elusive behavior) than with foraging (a conspicuous behavior). Literature on resource selection has rarely addressed behavioral differences in habitat use, although such differences are pervasive. Many animals require multiple, contrasting habitats on a daily or seasonal basis and depending on age or sex (Law \& Dickman 1998). For instance, short-toed larks Calandrella brachydactyla prefer areas dominated by short Salsola plants for nesting and avoid areas dominated by cereals for feeding (Serrano \& Astrain 2005). Black kites Milvus migrans prefer to nest in cliffs and trees at rugged sites, and prefer to forage near water and extensive grasslands within $1 \mathrm{~km}$ of nest sites (Sergio et al. 2003). Other bustards require relatively tall sward for concealment of nesting females and short sward for displaying males (Collar et al. 2017).

Finally, great Indian bustard usage at larger scales depended on the availability of useable and complementary resources at finer scales. Availability of complementary microhabitats was a better indicator of patch quality, measured as bird density/usage, compared to availability of resources for general occurrence. This pattern could arise if birds examine and select patches with higher diversity of useable microhabitats in a top-down process. Proximity to complementary resources can be energetically advantageous, as it reduces movement costs across larger areas to access spatially disjoint resources. This can attract more individuals and allow them to spend longer periods in an area. Multi-scale species-habitat analyses have commonly viewed habitat selection as a similar hierarchical process with choices made progressively from coarser to finer scales (Rettie \& Messier 2000, but see Mayor et al. 2009). Conversely, birds can directly select micro- 
habitats, and the naturally occurring habitat heterogeneity may allow them to use those areas more intensively where complementary resources are available in close proximity. This would be a bottomup process of habitat selection that has been largely undermined in hierarchical habitat studies.

\subsection{Study limitations}

This study has some shortcomings. Firstly, our inferences come from a diminishing population that may raise concerns over maladaptive habitat choice, causing the species to decline (Schlaepfer et al. 2002). We cannot eliminate this possibility in the absence of additional data on the species' fitness in different habitats. However, this scenario is unlikely since inferred resource characteristics largely matched with that of Rahmani (1989) when the population size was much larger and their habitat was less altered. Further, our understanding of the species suggests that past hunting and power-line collisions have contributed more to its decline than habitat loss (Dutta et al. 2011, M. Uddin \& S. Dutta, unpubl.). Secondly, RSFs based on direct observations have limitations, such as small samples of cryptic behaviors and pseudo-replication. Some cryptic behaviors can be better captured through telemetry (e.g. roosting and resting), while others are inherently rare/localized (courtship). However, models built on subsets of available locations showed similar covariate effects, indicating that sample sizes were likely adequate. The issue of pseudo-replication could arise because of repeated sampling of same individuals and their spatio-temporally auto-correlated behaviors. We tried avoiding this problem by sampling the area uniformly to capture several individuals, and restricting to only one 'used' location per behavior in an observation sequence. However, issues such as individuals' fidelity to nesting and other used sites could not be corrected. Thirdly, our sample size restricted us from exploring the effects of inter-annual variability (one sampling year experienced drought) and gender differences in habitat selection that need further examination.

\subsection{Conservation implications}

Despite the above issues, our finding that areas with heterogeneous swards and diverse microhabitats have greater use intensity carries strong management implications. Bustards range over large areas to access their widely dispersed resources, and this movement may increase fatal encounters with anthropogenic threats such as power-lines (Mahood et al. 2018). Despite the ongoing advocacy, existing power-lines are yet to be mitigated across several thousand square kilometers of bustard landscapes, because of large financial costs and political inertia. However, relatively smaller areas encompassing critical habitats can be secured on priority by burying power-lines. If these critical habitats are additionally managed to accommodate all behavioral requirements and annual life history needs, then longdistance movements of the species can be partly restricted. Although this measure can reduce the risk of power-line mortality to some extent, it is not a sufficient measure to eliminate this threat.

While much great Indian bustard habitat is lost or degraded, some relatively small breeding areas (5-15 $\left.\mathrm{km}^{2}\right)$ have been acquired by Forest Departments for restoration (following Dutta et al. 2013). Managing these reserves by incorporating missing resource units should benefit the species, according to our findings. In a larger context, as wildlife habitats are shrinking, management of structural heterogeneity leaves the possibility of increasing density/ usage within remnant habitats for species that are dependent on landscape complementation. Law \& Dickman (1998) invoked the need for maintaining a patchwork of habitats and active management of heterogeneity for conserving species that require habitat mosaics. Managing breeding habitats of great Indian bustards as mosaics of short and tall vegetation was recommended by Dutta et al. (2011) and Collar et al. (2017). Greater usage of areas with contrasting microhabitats, as shown by this study, bolsters this proposition.

Further, surrogacy is a popular management tool that draws conservation focus towards species with iconic, indicator or keystone values in the ecosystem (Caro \& O'Doherty 1999). We propose that species depending on heterogeneous habitats can be good conservation proxies. Within the wide range of microhabitats used by great Indian bustards, other sympatric species are nested. The associated spinytailed lizard Saara hardwickii and Indian courser Cursorius coromandelicus prefer short swards, whereas chinkara Gazella bennettii and quails Coturnix spp. prefer moderate height swards (Dutta \& Jhala 2014, S. Dutta pers. obs.). Targeting such species for conservation finds resonance in the wellestablished 'habitat heterogeneity hypothesis' that postulates higher species diversity because of more niches in structurally complex environments (David- 
owitz \& Rosenzweig 1998). A meta-analysis of this effect has found positive relationship between habitat heterogeneity and animal species diversity in $85 \%$ of studies (Tews et al. 2004).

Finally, in our study, behavioral ecology meets conservation management through resource selection analysis. We show that the key to effectively manage critical habitats for a Critically Endangered bird lies in the 'detail' of microhabitat differences between behaviors. Statistical models of habitat use that ignore these differences were poor indicators of habitat suitability and will be non-informative for species relying on habitat mosaics. At best, they can predict occurrence of the species, but not why it occurs there, which is pivotal to its conservation.

Acknowledgements. The Wildlife Institute of India funded this research. We are grateful to the Director, Dean and Research Coordinator of the Institute for administrative support. We thank the Chief Wildlife Warden of Gujarat and the state Forest Department for granting research permission. We specially thank I. P. Bopanna and K. Maurya for their support during fieldwork, and B. Jethva for data sharing and research inputs. We are grateful to I. Bhatti, L. S. Negi, R. Negi, I. Mundra, S. Maheshwari, L. Paradi and D. Paradi for field assistance. We also thank A. Rahmani for his input in an earlier version of the manuscript, and S. Bisht for preliminary proofreading. Finally, we thank 3 anonymous reviewers for their constructive comments to improve the manuscript.

\section{LITERATURE CITED}

Akaike H (1974) A new look at the statistical model identification. IEEE Trans Automat Contr 19:716-723

Baasch DM, Tyre AJ, Millspaugh JJ, Hygnstrom SE, Vercauteren KC (2010) An evaluation of three statistical methods used to model resource selection. Ecol Model 221:565-574

BirdLife International (2018) Great Indian bustard Ardeotis nigriceps. The IUCN Red List of Threatened Species 2018:e.T22691932A134188105. https://dx.doi.org/10.2305/ IUCN.UK.2018-2.RLTS.T22691932A134188105.en

Boyce MS (2006) Scale for resource selection functions. Divers Distrib 12:269-276

*Boyce MS, McDonald LL (1999) Relating populations to habitats using resource selection functions. Trends Ecol Evol 14:268-272

Bretagnolle V, Villers A, Denonfoux L, Cornulier $T$, Inchausti P, Badenhausser I (2011) Rapid recovery of a depleted population of little bustards Tetrax tetrax following provision of alfalfa through an agri-environment scheme. Ibis 153:4-13

Burnham KP, Anderson DR (2002) Model selection and multimodel inference: a practical information-theoretic approach, $2^{\text {nd }}$ edn. Springer, New York, NY

Burnham KP, Anderson DR, Laake JL (1980) Estimation of density from line transect sampling of biological populations. Wildl Monogr 72:3-202

Butchart SHM, Stattersfield AJ, Bennun LA, Shutes SM and others (2004) Measuring global trends in the status of biodiversity: Red List indices for birds. PLOS Biol 2:e383

*Caro TM, O'Doherty G (1999) On the use of surrogate species in conservation biology. Conserv Biol 13:805-814

Champion HG, Seth SK (1968) A revised survey of the forest types of India. Government of India, New Delhi

Choquenot D, Ruscoe WA (2003) Landscape complementation and food limitation of large herbivores: habitatrelated constraints on the foraging efficiency of wild pigs. J Anim Ecol 72:14-26

Cody ML (1985) Habitat selection in birds. Academic Press, London

Collar NJ, Baral HS, Batbayar N, Bhardwaj GS and others (2017) Averting the extinction of bustards in Asia. Forktail 33:1-26

Davidowitz G, Rosenzweig ML (1998) The latitudinal gradient of species diversity among North American grasshoppers (Acrididae) within a single habitat: a test of the spatial heterogeneity hypothesis. J Biogeogr 25:553-560

* Dunning JB, Danielson BJ, Pulliam HR (1992) Ecological processes that affect populations in complex landscapes. Oikos 65:169-175

Dutta S (2012) Ecology of the great Indian bustard (Ardeotis nigriceps) in Kachchh, Gujarat with reference to resource selection in an agro-pastoral landscape. $\mathrm{PhD}$ dissertation, Forest Research Institute, Dehradun

Dutta S (2018) Greener on neither side: socio-ecological crisis of dry grasslands in India. In: Sreenivasan U, Velho N (eds) Conservation from the margins. Orient Blackswan, Hyderabad, p 198-231

* Dutta S, Jhala Y (2014) Planning agriculture based on landuse responses of threatened semiarid grassland species in India. Biol Conserv 175:129-139

* Dutta S, Rahmani AR, Jhala YV (2011) Running out of time? The great Indian bustard Ardeotis nigriceps-status, viability, and conservation strategies. Eur J Wildl Res 57: $615-625$

Dutta S, Rahmani A, Gautam P, Kasambe R, Narwade S, Narayan G, Jhala Y (2013) Guidelines for preparation of state action plan for resident bustards' recovery programme. Ministry of Environment and Forests, Government of India, New Delhi

Graham MH (2003) Confronting multicollinearity in ecological multiple regression. Ecology 84:2809-2815

* Gray TN, Chamnan H, Borey R, Collar NJ, Dolman PM (2007) Habitat preferences of a globally threatened bustard provide support for community-based conservation in Cambodia. Biol Conserv 138:341-350

* Gray TN, Chamnan H, Collar NJ, Dolman PM (2009) Sexspecific habitat use by a lekking bustard: conservation implications for the critically endangered Bengal florican (Houbaropsis bengalensis) in an intensifying agroecosystem. Auk 126:112-122

F Green RE (1996) Factors affecting the population density of the corncrake Crex crex in Britain and Ireland. J Appl Ecol 33:237-248

*Hilbert DW, Swift DM, Detling JK, Dyer MI (1981) Relative growth rates and the grazing optimization hypothesis. Oecologia 51:14-18

*Hingrat Y, Saint Jalme M, Chalah T, Orhant N, Lacroix F (2008) Environmental and social constraints on breeding site selection. Does the exploded-lek and hotspot model apply to the houbara bustard Chlamydotis undulata undulata? J Avian Biol 39:393-404

*Hovick TJ, Elmore RD, Fuhlendorf SD (2014) Structural heterogeneity increases diversity of non-breeding grassland birds. Ecosphere 5:62 
IUCN (2018) The IUCN Red List of threatened species. Version 2018-2. www.iucnredlist.org (accessed 5 Feb 2021)

Jerrentrup JS, Wrage-Mönnig N, Röver KU, Isselstein J (2014) Grazing intensity affects insect diversity via sward structure and heterogeneity in a long-term experiment. J Appl Ecol 51:968-977

Johnsgard PA (1991) Birds of dry places: bustards, hemipodes and sandgrouse. Oxford University Press, New York, NY

Johnson CJ, Nielsen SE, Merrill EH, McDonald TL, Boyce MS (2006) Resource selection functions based on useavailability data: theoretical motivation and evaluation methods. J Wildl Manag 70:347-357

Jost L (2006) Entropy and diversity. Oikos 113:363-375

Koshkin MA, Collar NJ, Dolman PM (2014) Do sheep affect distribution and habitat of Asian houbara Chlamydotis macqueenii? J Arid Environ 103:53-62

Koshkin M, Burnside RJ, Packman CE, Collar NJ, Dolman PM (2016) Effects of habitat and livestock on nest productivity of the Asian houbara Chlamydotis macqueenii in Bukhara Province, Uzbekistan. Eur J Wildl Res 62: 447-459

Lane SJ, Alonso JC, Alonso JA, Naveso MA (1999) Seasonal changes in diet and diet selection of great bustards (Otis t. tarda) in north-west Spain. J Zool 247:201-214

* Lane SJ, Alonso JC, Martín CA (2001) Habitat preferences of great bustard Otis tarda flocks in the arable steppes of central Spain: Are potentially suitable areas unoccupied? J Appl Ecol 38:193-203

Lavee D (1988) Why is the houbara Chlamydotis undulata macqueenii still an endangered species in Israel? Biol Conserv 45:47-54

Law BS, Dickman CR (1998) The use of habitat mosaics by terrestrial vertebrate fauna: implications for conservation and management. Biodivers Conserv 7:323-333

MacDonald AJ, Mayer P, Armstrong HM, Immirzi, P, Reynolds P (1998) A guide to upland habitats. Surveying Land Management Impacts. Scottish Natural Heritage, Battleby

* Magana M, Alonso JC, Martin CA, Bautista LM, Martin B (2010) Nest-site selection by great bustards Otis tarda suggests a trade-off between concealment and visibility. Ibis 152:77-89

Mahood SP, Silva JP, Dolman PM, Burnside RJ (2018) Proposed power transmission lines in Cambodia constitute a significant new threat to the largest population of the Critically Endangered Bengal florican Houbaropsis bengalensis. Oryx 52:147-155

Manly BF, McDonald LL, Thomas DL, McDonald TL, Erickson WP (2002) Introduction to resource selection studies. Resource selection by animals: statistical design and analysis for field studies, Kluwer Academic Publishers, New York, NY

Mayor SJ, Schneider DC, Schaefer JA, Mahoney SP (2009) Habitat selection at multiple scales. Ecoscience 16: 238-247

McCullagh P, Nelder JA (1989) Generalized linear models, $2^{\text {nd }}$ edn. Monogr Stat Appl Prob 37. Chapman \& Hall/ CRC, Boca Raton, FL

* Nad'o L, Kaňuch P (2018) Why sampling ratio matters: logistic regression and studies of habitat use. PLOS ONE 13: e0200742

O'Brien M, Green RE, Wilson J (2006) Partial recovery of the population of corncrakes Crex crex in Britain, 19932004. Bird Study 53:213-224
Osborne PE, Alonso JC, Bryant RG (2001) Modelling landscape-scale habitat use using GIS and remote sensing: a case study with great bustards. J Appl Ecol 38:458-471

Quinn GP, Keough MJ (2002) Experimental design and data analysis for biologists. Cambridge University Press, Cambridge

R Core Team (2013) R: a language and environment for statistical computing. R Foundation for Statistical Computing, Vienna

Rahmani AR (1989) Study of ecology of certain endangered species of wildlife and their habitats: the great Indian bustard. Final report. Bombay Natural History Society, Bombay

Rettie WJ, Messier F (2000) Hierarchical habitat selection by woodland caribou: its relationship to limiting factors. Ecography 23:466-478

Rushton SP, Ormerod SJ, Kerby G (2004) New paradigms for modelling species distributions? J Appl Ecol 41:193-200

* Sastre P, Ponce C, Palacín C, Martín CA, Alonso JC (2009) Disturbances to great bustards (Otis tarda) in central Spain: human activities, bird responses and management implications. Eur J Wildl Res 55:425-432

Schlaepfer MA, Runge MC, Sherman PW (2002) Ecological and evolutionary traps. Trends Ecol Evol 17:474-480

Sergio F, Pedrini P, Marchesi L (2003) Adaptive selection of foraging and nesting habitat by black kites (Milvus migrans) and its implications for conservation: a multiscale approach. Biol Conserv 112:351-362

* Serrano D, Astrain C (2005) Microhabitat use and segregation of two sibling species of Calandrella larks during the breeding season: conservation and management strategies. Biol Conserv 125:391-397

Shoemaker KT, Heffelfinger LJ, Jackson NJ, Blum ME, Wasley T, Stewart KM (2018) A machine-learning approach for extending classical wildlife resource selection analyses. Ecol Evol 8:3556-3569

SoIB (2020) State of India's Birds, 2020: range, trends and conservation status. The SoIB Partnership, India

Stephens DW, Krebs JR (1986) Foraging theory. Princeton University Press, Princeton, NJ

Tews J, Brose U, Grimm V, Tielbörger K, Wichmann MC, Schwager M, Jeltsch F (2004) Animal species diversity driven by habitat heterogeneity/diversity: the importance of keystone structures. J Biogeogr 31:79-92

*Thomas L, Buckland ST, Rexstad EA, Laake JL and others (2010) Distance software: design and analysis of distance sampling surveys for estimating population size. J Appl Ecol 47:5-14

* Tilman D, May RM, Lehman CL, Nowak MA (1994) Habitat destruction and the extinction debt. Nature 371:65-66

* Tourenq C, Combreau O, Lawrence M, Pole SB and others (2005) Alarming houbara bustard population trends in Asia. Biol Conserv 121:1-8

*Van Heezik YV, Seddon PJ (1999) Seasonal changes in habitat use by houbara bustards Chlamydotis [undulata] macqueenii in northern Saudi Arabia. Ibis 141:208-215

Vittinghoff E, McCulloch CE (2007) Relaxing the rule of ten events per variable in logistic and Cox regression. Am J Epidemiol 165:710-718

White RP, Murray S, Rohweder M, Prince SD, Thompson KM (2000) Grassland ecosystems. World Resources Institute, Washington, DC

Wolff A, Paul JP, Martin JL, Bretagnolle V (2001) The benefits of extensive agriculture to birds: the case of the little bustard. J Appl Ecol 38:963-975

Submitted: September 15, 2020

Accepted: March 16, 2021

Proofs received from author(s): May 19, 2021
Editorial responsibility: Michael Reed,
Medford, Massachusetts, USA

Reviewed by: 3 anonymous referees 